\title{
PROCESS OPTIMISATION OF 1,3-PROPANEDIOL PRODUCTION BY Klebsiella pneumoniae STRAIN
}

\section{STASHA ELEANOR ROSLAND ABEL* and SOH KHEANG LOH*}

\begin{abstract}
The 1,3-propanediol (1,3-PD) is a versatile chemical feedstock with a wide range of applications: cosmetic, food and polymers synthesis. Although 1,3-PD is conventionally chemically synthesised, it has drawbacks such as requiring high pressure and temperature. Therefore, a more economical biological approach to produce 1,3-PD is crucial. This study attempted to investigate the effects of common fermentation parameters temperature, $p H$, glycerol concentration and inoculum size on the production of 1,3-PD by Klebsiella pneumoniae via one-factor-at-a-time (OFAT) method. The optimised conditions: temperature, $34^{\circ} \mathrm{C} ; \mathrm{pH}$, 7.5; glycerol concentration, $30 \mathrm{~g}$ litre $^{-1}$ and inoculum size, $20 \%$ (v/v) showed 1.78-fold increase in 1,3-PD production, i.e. from the initial $4.89 \mathrm{~g} \mathrm{litre}^{-1}$ to $8.70 \mathrm{~g} \mathrm{litre}^{-1}$ in shake flask experiment after $48 \mathrm{hr}$. The 1,3PD productivity by K. pneumoniae was higher $\left(0.18 \mathrm{glitre}^{-1} \mathrm{hr}^{-1}\right)$ from the unoptimised conditions $(0.07$ $\mathrm{g}$ litre-1 $\left.\mathrm{hr}^{-1}\right)$. The other parameter studied - varying nitrogen sources in the fermentation medium - revealed that their addition unexpectedly did not show any improvement in 1,3-PD production unlike those reported in the literature. It can be concluded that both glycerol concentration and incubation temperature were the most significant factors in producing higher 1,3-PD yield.
\end{abstract}

Keywords: 1,3-propanediol; glycerol; Klebsiella pneumoniae; one-factor-at-a-time method, optimisation.

Date received: 5 April 2018; Sent for revision: 6 April 2018; Received in final form: 11 July 2018; Accepted: 17 July 2018.

\section{INTRODUCTION}

As fossil fuel has become increasingly scarce, development of biobased materials and products for economy sustainability is crucial (Ragauskas et al., 2006). Materials that are renewable and biodegradable, e.g. biodiesel could attract considerable public attention (Andrade and Vasconcelos, 2003; Xu et al., 2003). Biodiesel has increasingly been considered in establishing biorefineries; the challenges faced is to handle the surplus amounts of by-product generated, i.e. crude glycerol. So far, the disposal of waste glycerol has negatively impacted the environment and is costly. Thus, it is vital to develop processes to convert glycerol into commercially viable products in sustaining the biodiesel industry. One possibility

\footnotetext{
Malaysian Palm Oil Board

6 Persiaran Institusi, Bandar Baru Bangi,

43000 Kajang, Selangor, Malaysia.

E-mail: stasha.eleanor@mpob.gov.my
}

is transforming crude glycerol into 1,3-propanediol (1,3-PD), citric acid or succinic acid as it has triglyceride-based natural substrate susceptible to microbial degradation (Pagliaro et al., 2007).

The 1,3-PD, a C3-dihydroxy monomer has gained an economic importance for being a specialty chemical from commodity bulk chemicals. It has wide applications, e.g. as food additive, raw material in pharmaceutical, cosmetic ingredient and intermediate for biocides and heterocyclic compounds synthesis (Jong et al., 2011; Lee et al., 2015). Nearly $90 \%$ of $1,3-\mathrm{PD}$ is used in plastic industry as a monomer for polyester polytrimethylene terephthalate (PTT) synthesis. The 1,3-PD-based polyester, coil-like or zig-zag shaped, has better characteristics including better stretch ability, lower dyeing temperature, higher UV resistance and better wash-fastness property than other commercially available polyesters.

The conventional syntheses of 1,3-PD through hydration of acrolein and hydroformylation of 
ethylene oxide have several drawbacks, while alternative microbial process could be more efficient owing to its renewability, environmentalfriendliness and low-cost (Dietz and Zeng, 2014; Lee et al., 2015). Microbial fermentation of glycerol into 1,3-PD has been known for more than 137 years with its first production in 1881 by Freund (Zeng and Biebl, 2002). Many microbial species namely Kluyvera (Loh and Stasha, 2016), Klebsiella (Wojtusik et al., 2015), Citrobacter (Drozdzynska et al., 2014), Clostridium (Johnson and Rehmann, 2016), Lactobacillus (Maria et al., 2015) and Shimwellia blattae (Rodriguez et al., 2015) show potential in 1,3-PD production. Among the exploited strains, Klebsiella pneumoniae has been extensively studied in support of its simpler metabolic pathways involved for potential improvement.

Previously, optimisation process for a higher 1,3-PD production has been performed via Response Surface Methodology (RSM) (Stasha and Loh, 2017). However, its production via simpler optimisation method is most desirable. The individual effects of various processing factors can be determined without the need of statistical tools. Hence, optimisation of 1,3-PD using K. pneumoniae strain was carried out via conventional one-factorat-a-time (OFAT) approach, then compared with that optimised statistically, and the more feasible approach in 1,3-PD production will be drawn. The important culture conditions, i.e. temperature, $\mathrm{pH}$, glycerol concentration and inoculum size on 1,3PD production were evaluated. On top of that, the influence of varying nitrogen sources supplemented in the fermentation medium on 1,3-PD formation was investigated and their performance efficiency evaluated.

\section{MATERIALS AND METHODS}

\section{Composition of Crude Glycerol, Fermentation Medium and Microorganism}

Crude glycerol obtained from Sime Darby Biodiesel Sdn Bhd (Selangor, Malaysia) was the sole carbon source used in the medium for fermentation (Table 1). The chemicals used: $\mathrm{K}_{2} \mathrm{HPO}_{4}, \mathrm{KH}_{2} \mathrm{PO}_{4}$ $\left(\mathrm{NH}_{4}\right)_{2} \mathrm{SO}_{4}, \quad \mathrm{MgSO}_{4} \cdot 7 \mathrm{H}_{2} \mathrm{O}, \quad \mathrm{MnSO}_{4} \cdot 4 \mathrm{H}_{2} \mathrm{O}, \quad \mathrm{ZnCl}_{2}$

TABLE 1. COMPOSITION OF CRUDE GLYCEROL FROM SIME DARBY BIODIESEL SDN BHD

\begin{tabular}{cc}
\hline Component & Concentration $\%(w / v)$ \\
\hline Glycerine & 79.3 \\
Water & 6.69 \\
Soap & 16.2 \\
Methanol & 7.3 \\
Oil & 0.97 \\
\hline
\end{tabular}

$\mathrm{Na}_{2} \mathrm{MoO}_{4} .2 \mathrm{H}_{2} \mathrm{O}, \mathrm{H}_{3} \mathrm{BO}_{3} \mathrm{CoCl}_{2} \cdot 6 \mathrm{H}_{2} \mathrm{O}, \mathrm{CuSO}_{4} .5 \mathrm{H}_{2} \mathrm{O}$, $\mathrm{NiCl}_{2} \cdot 6 \mathrm{H}_{2} \mathrm{O}$ and $37 \% \mathrm{HCl}$ were purchased from Sigma-Aldrich (USA) and Merck. K. pneumoniae K47, purchased from Unit of Bacteriology, Institute for Medical Research (IMR), Kuala Lumpur was the strain used for fermentation of crude glycerol.

\section{Cultivation of Klebsiella pneumoniae}

The K. pneumoniae strain was maintained in a medium containing $\left(\mathrm{g}\right.$ litre $\left.{ }^{-1}\right)$ : yeast extract, 5; peptone, 10; $\mathrm{NaCl}$, 9; glycerol, 20 and agar, 20. For starter culture, the strain was grown on medium consisting of all the above components except agar. The fermentation medium of 1,3-PD consisting (g litre ${ }^{-1}$ ): glycerol, 20; $\mathrm{K}_{2} \mathrm{HPO}_{4}, 0.69 ; \mathrm{KH}_{2} \mathrm{PO}_{4}, 0.25$; $(\mathrm{NH} 4)_{2} \mathrm{SO}_{4}, 6 ; \mathrm{MgSO}_{4} .7 \mathrm{H}_{2} \mathrm{O}, 0.2$; yeast extract, 1.5 and $1 \mathrm{ml}$ of trace element solution (Stasha and Loh, 2017). The cultivation was performed in 250 $\mathrm{ml}$ Erlenmeyer flasks each containing $100 \mathrm{ml}$ of the fermentation medium.

\section{Analytical Methods}

Samples were withdrawn from the flask at every $6^{\text {th }}, 12^{\text {th }}, 24^{\text {th }}, 48^{\text {th }}$ and $72^{\text {nd }}$ hr interval to measure optical density $\left(\mathrm{OD}_{600 \mathrm{~nm}}\right), \mathrm{pH}$, glycerol and 1,3-PD concentration. The culture was centrifuged at 1431 $\times \mathrm{g}$ for $10 \mathrm{~min}$ to remove cells and the supernatant was then filtered through a $0.45-\mu \mathrm{m}$ membrane filter (Nylon) and analysed using high performance liquid chromatography (HPLC) (Waters 2707 Autosampler). The mobile phase employed was sulphuric acid $(0.5 \mathrm{mM})$ at a flow rate of $1.0 \mathrm{ml}$ $\mathrm{min}^{-1}$. Samples were injected and metabolites were analysed at $60^{\circ} \mathrm{C}$. Cell growth as reflected by $\mathrm{OD}_{600 \mathrm{~nm}}$ was determined by a UV spectrophotometer (Genesys 20 visible spectrophotometer, Thermo Scientific) at a wavelength of $600 \mathrm{~nm}$. The initial and the final $\mathrm{pH}$ of culture medium were analysed using a pH meter (HANNA Instruments, model 211). All experimental trials were conducted in triplicate.

\section{Optimisation of 1,3-PD Production}

Different culture conditions that may influence the yield of 1,3-PD including incubation temperature $\left(30^{\circ} \mathrm{C}-40^{\circ} \mathrm{C}\right)$, initial medium $\mathrm{pH}$ (68), substrate concentration (10 g litre ${ }^{-1}-50 \mathrm{~g}_{\text {litre }}{ }^{-1}$ ), inoculum size $(3 \%-20 \%)$ and nutrient supplement (nitrogen sources: urea, peptone, meat extract, yeast extract, ammonium chloride and ammonium sulfate) each at $5.0 \mathrm{~g}$ litre $^{-1}$ were evaluated for 1,3PD production by $K$. pneumoniae in shake-flask fermentation. The effect of nitrogen sources was studied as they supplied additional nutrients which might enhance 1,3-PD production. The influence of temperatures on 1,3-PD production was carried out by varying the temperature at $30^{\circ} \mathrm{C}, 34^{\circ} \mathrm{C}, 37^{\circ} \mathrm{C}$ and 
$40^{\circ} \mathrm{C}$. The flasks were inoculated with fresh cultures and incubated under $150 \mathrm{rpm}$ agitation rate for 72 hr. The experiments were carried out at various pH values: 6.0, 6.5, 7.0, 7.5 and 8.0. The medium's $\mathrm{pH}$ was adjusted with $1 \mathrm{M} \mathrm{NaOH} / \mathrm{HCl}$ before sterilisation. The effect of substrate concentration on 1,3-PD production was studied by varying the glycerol concentrations: $10 \mathrm{~g}$ litre $^{-1}, 20 \mathrm{~g}$ litre $^{-1}$, $30 \mathrm{~g}$ litre $^{-1}, 40 \mathrm{~g}_{\text {litre }}{ }^{-1}$ and $50 \mathrm{~g}$ litre $^{-1}$. To evaluate the effect of varying inoculum size, 3\%, 5\%,10\%,15\% and 20\% $(\mathrm{v} / \mathrm{v})$ of the culture were added to the fermentation medium.

\section{RESULTS AND DISCUSSION}

\section{Effect of Incubation Temperature on 1,3-PD Production}

Incubation temperature $\left(30^{\circ} \mathrm{C}, 34^{\circ} \mathrm{C}, 37^{\circ} \mathrm{C}\right.$ and $40^{\circ} \mathrm{C}$ ) is a critical factor in $\mathrm{K}$. pneumoniae growth. Figure 1 shows a remarkable change in 1,3-PD production at different incubation temperatures. At $34^{\circ} \mathrm{C}$ and $40^{\circ} \mathrm{C}$, the strain was found to be metabolically more active with higher 1,3-PD production (8.62 $\mathrm{g}_{\text {litre }} \mathrm{-}^{-1}$ and $8.49 \mathrm{~g} \mathrm{litre}^{-1}$ ) after 72 hr, compared to those at $30^{\circ} \mathrm{C}$ and $37^{\circ} \mathrm{C}$ which were less active $\left(7.51 \mathrm{~g}\right.$ litre $^{-1}$ and $\left.6.21 \mathrm{~g} \mathrm{litre}^{-1}\right)$. Thus, the optimal temperature acquired was $34^{\circ} \mathrm{C}$. The variations in different incubation temperatures were due to the different nature of microorganism and its environmental conditions. Zhao et al. (2017) performed shake-flask fermentation using a strain of K. pneumonia ZH-1 and producing higher 1,3-PD yield of $19.93 \mathrm{~g} \mathrm{litre}^{-1}$ at optimum temperature of $36^{\circ} \mathrm{C}$. Other studies by Sattayasamitsathit et al. (2011) and Guo et al. (2017) reported a suitable temperature at $37^{\circ} \mathrm{C}$ for $1,3-\mathrm{PD}$ biosynthesis.

\section{Effect of Initial pH Value on 1,3-PD Production}

The $\mathrm{pH}$ influences metabolic activity and growth of K. pneumoniae in fermentation of crude glycerol. The results showed that a change in $\mathrm{pH}$ would alter the growth of K. pneumoniae and influence 1,3PD production. A higher amount of 1,3-PD (7.31 g litre $^{-1}$ ) was produced by K. pneumoniae at initial $\mathrm{pH}$ of 7.5 followed by $6.42 \mathrm{~g}$ litre $^{-1}$ at $\mathrm{pH} 8$ after $72 \mathrm{hr}$ of fermentation (Figure 2a). Lower range of $\mathrm{pH}$ (6-7) gave lower production of 1,3-PD (3.96 g litre lo $^{-1}$ to $\left.6.03 \mathrm{~g} \mathrm{litre}^{-1}\right)$. The 1,3-PD production rates increased with increasing initial $\mathrm{pH}$ values. This agreed with the studies by Zhao et al. (2017) and Moscoviz et al. (2016) that maximum concentration of 1,3-PD was achieved at $\mathrm{pH}$ 7.0-8.0. As such, a slightly acidic condition had a negative effect on 1,3-PD production (Kang et al., 2013). In Figure 2b, crude glycerol was rapidly consumed and its concentration depleted tremendously around 24-72 $\mathrm{hr}$ in all the $\mathrm{pH}$ levels employed.

The $\mathrm{pH}$ range (6.0-6.5) showed a slower rate of glycerol consumption corresponding to the above findings. The highest 1,3-PD production rate was at $\mathrm{pH}$ 7.5-8.0, thus indicating that slightly alkaline condition could enhance 1,3-PD yield and productivity. At the end of the fermentation (72 hr), the average final $\mathrm{pH}$ at all temperatures employed was $5.07 \pm 0.55$ and the production of $1,3-\mathrm{PD}$ reduced compared to those at higher initial $\mathrm{pH}$ values and shorter fermentation time. This result showed that

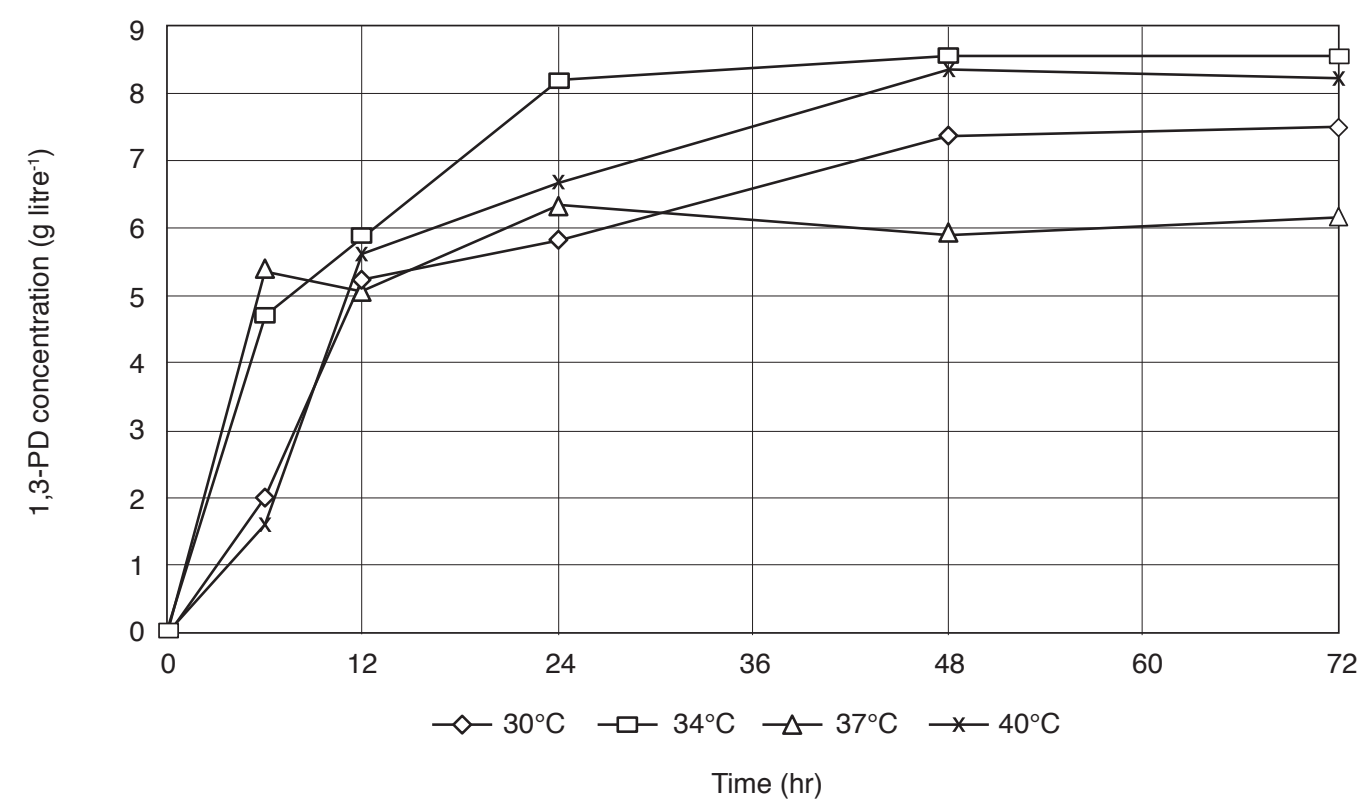

Figure 1. The 1,3-propanediol (1,3-PD) concentration by K. pneumoniae at different incubation temperature in shake-flask culture at $150 \mathrm{rpm}$ for $72 \mathrm{hr}$. 

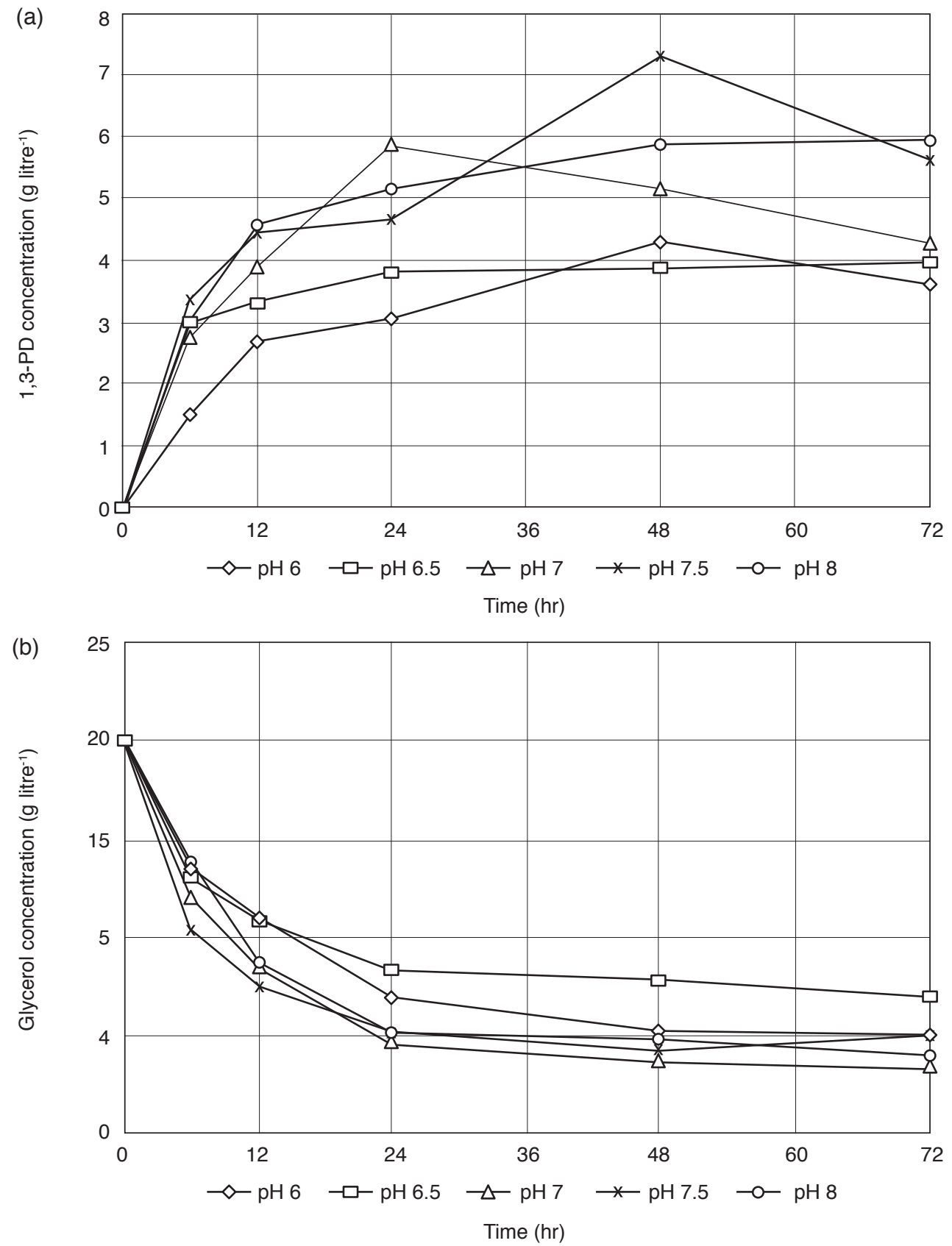

Figure 2. (a) Production of 1, 3-propanediol (1,3-PD) and (b) glycerol residual at $34^{\circ} \mathrm{C}, 150 \mathrm{rpm}$ for $72 \mathrm{hr}$.

the final $\mathrm{pH}$ had inhibited the process probably due to the presence of organic acids which could have been synthesised during the metabolic pathway.

\section{Effect of Substrate Concentration on 1,3-PD Production}

The time course study on various concentration of glycerol (10 $\mathrm{g}_{\text {litre }}^{-1}-50 \mathrm{~g}$ litre $\left.^{-1}\right)$ (Figure 3 ) showed the highest 1,3-PD concentration (7.32 $\mathrm{g}^{-1}$ litre ${ }^{-1}-7.43$ $\mathrm{g}$ litre $^{-1}$ ) and productivity of $0.152 \mathrm{~g}$ litre $^{-1} \mathrm{hr}^{-1}-0.103$ $\mathrm{g}$ litre $\mathrm{err}^{-1}$ was achieved at glycerol concentration of $20 \mathrm{~g}$ litre $^{-1}$ and $30 \mathrm{~g}^{-1}$ lite $^{-1}$. The lowest was $4.21 \mathrm{~g}$ litre $^{-1}$ when $10 \mathrm{~g}$ litre $^{-1}$ of crude glycerol was used. Further increase in glycerol concentration to 40 $\mathrm{g}$ litre $^{-1}$ and $50 \mathrm{~g}$ litre $^{-1}$ however, had resulted in a declined production (7.28 g litre $\mathrm{e}^{-1}$ and $6.87 \mathrm{~g} \mathrm{litre}^{-1}$, respectively). This indicated that inhibition of cell growth of K. pneumoniae could occur at higher glycerol concentration $\left(>30 \mathrm{~g}^{\text {litre }}{ }^{-1}\right)$, probably due to higher level of impurities such as soap, methanol and free fatty acids which could affect the microbial performance during fermentation of crude glycerol. Previous studies by Papanikolaou et al. (2004) and Jalasutram and Jetty (2011) have reported similar findings, where the production rate of 1,3-PD decreases with increasing glycerol concentration. Of all the concentrations employed, $30 \mathrm{~g}$ of crude glycerol showed optimum 1,3-PD production, i.e. $7.42 \mathrm{~g} \mathrm{litre}^{-1}$. Zhang et al. (2007) stated that the 


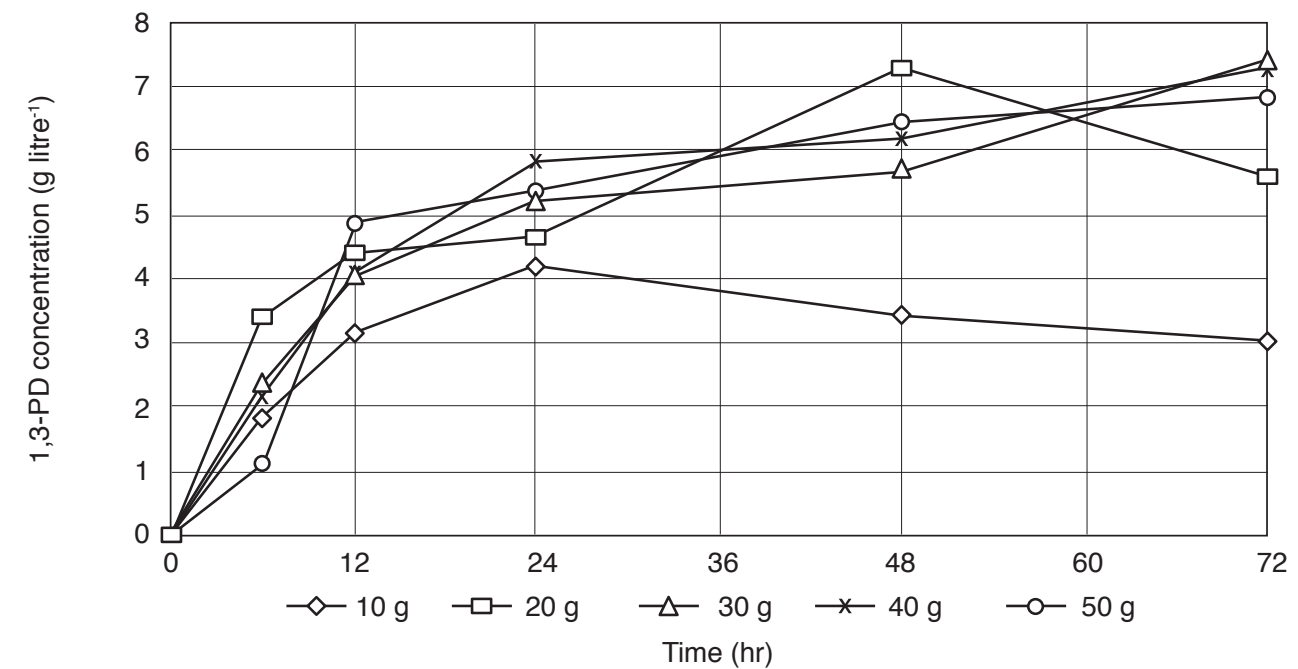

Figure 3. Time course of 1, 3-propanediol (1,3-PD) production at different initial concentration in shake-flask culture at $34^{\circ} \mathrm{C}$, pH 7.5, 150 rpm for $72 \mathrm{hr}$.

formation of products during fermentation process of 1,3-PD was influenced by concentration of crude glycerol which acted as a carbon and energy source.

\section{Effect of Different Inoculum Size on 1,3-PD Production}

Microorganism could perform most efficiently if the right substrate concentration, i.e. inoculum size was provided. The amount of inoculum is vital as it can significantly influence the lag phase duration, specific growth rate, biomass yield and the quality of final product during fermentation. This study aimed to observe the relationship between the percentage of inoculum and the 1,3-PD production. Figure 4 reveals that the maximum 1,3-PD production could be achieved using $20 \%$ inoculum size of $K$. pneumoniae yielding $8.70 \mathrm{~g} \mathrm{litre}^{-1}$ 1,3-PD with productivity of $0.18 \mathrm{~g}$ litre $^{-1} \mathrm{hr}^{-1}$ for $72 \mathrm{hr}$. The production was very little at $3 \%$ and $10 \%$ inoculum size, but greatly increased when $15 \%$ to $20 \%$ inoculum size was used. Increasing the inoculums size will increase the number of $K$. pneumonia cells in the medium which will considerably affect the growth rate and 1,3-PD production. The results showed that inoculum size lower than $20 \%$ tends to reduce 1,3-PD production. However, studies by Zhao et al. (2017) and Guo et al. (2017) revealed that inoculum size of $>10 \%$ triggered lower formation activity of 1,3-PD. This is probably due to glycerol utilisation for cell growth and disproportionation was reduced, hence affecting 1,3-PD yield.

\section{Effect of Nitrogen Sources on 1,3-PD Production}

The 1,3-PD production can be enhanced by nitrogen (protein) supplement which is necessary for cell metabolism and construction as it comprises $8 \%-14 \%$ of dry cell mass of bacteria. The growth of K. pneumoniae varied at same concentrations $(5.0$

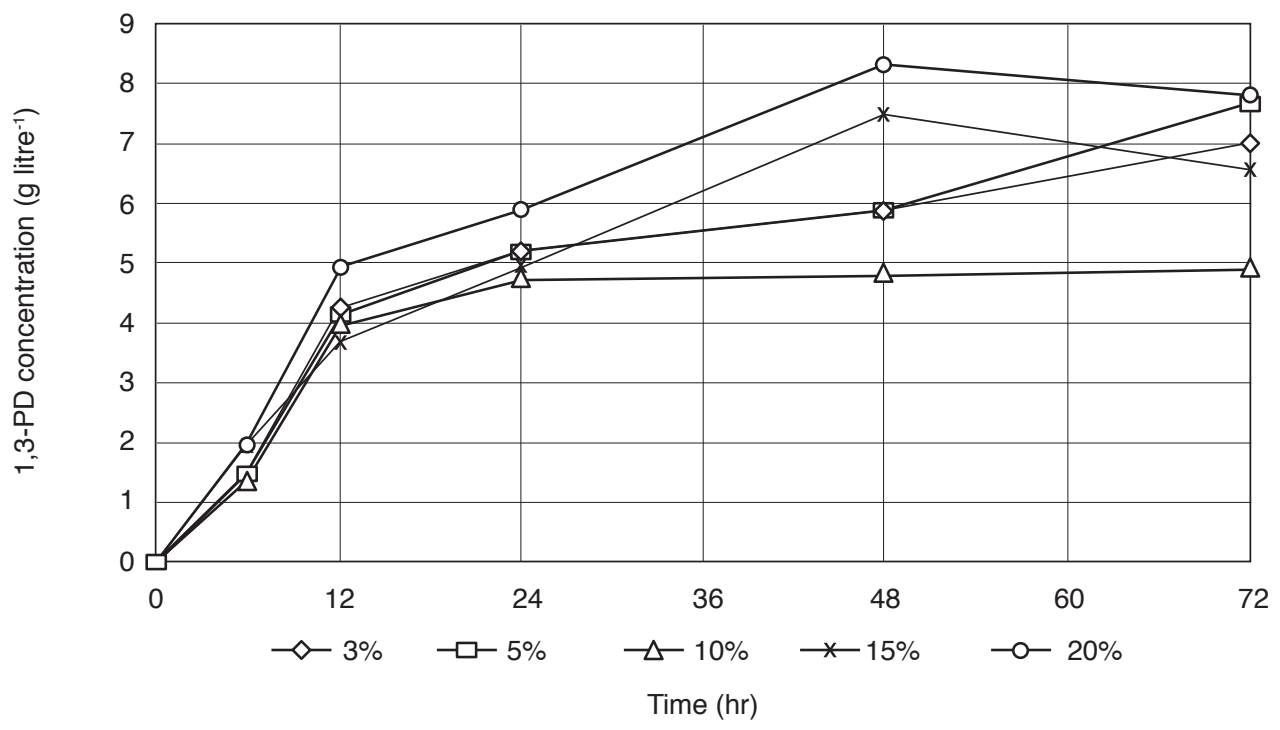

Figure 4. Effect of different inoculum size on 1, 3-propanediol (1,3-PD) production by K. pneumoniae. 
$\left.\mathrm{g}_{\text {litre }}{ }^{-1}\right)$ of different nitrogen sources used. The fermentation profile for 1,3-PD production (Figure $5 a$ ) and glycerol degradation (Figure $5 b$ ) showed that the order of optimum production of 1,3-PD under the influence of various nitrogen sources was yeast extract $>$ meat extract $>$ ammonium chloride $>$ urea $>$ ammonium sulphate $>$ peptone. The highest 1,3-PD yields of $7.97 \mathrm{~g}_{\text {litre }}^{-1}$ and $7.10 \mathrm{~g}^{\text {litre }}{ }^{-1}$ were obtained in media containing yeast extract followed by meat extract, respectively.

However, addition of peptone and ammonium sulphate slightly downgraded the bacteria growth, thus generated less 1,3-PD, $4.81 \mathrm{~g}$ litre $^{-1}$ and $5.46 \mathrm{~g}$ litre $^{-1}$, respectively. This occurred probably due to insufficient nutrients that could satisfy no more than the minimal requirement for growth. The amount of 1,3-PD generated in media containing varying nitrogen sources is lower than the optimised value thus, the role of nitrogen source in improving 1,3PD production is least significant. This result is consistent with previous study by Jalasutram et al. (2011)

\section{Comparison between OFAT and RSM}

Table 2 compares the results obtained via OFAT and RSM. The OFAT approach gave $29 \%$ of glycerolto-1,3-PD conversion yielding $8.70 \mathrm{~g}$ litre $^{-1}$ from an initial $30 \mathrm{~g}$ litre $^{-1}$ within $48 \mathrm{~h}$ incubation time. Based on RSM, 1,3-PD produced was slightly higher $(9.85$ $\mathrm{g} \mathrm{litre}^{-1}$ ) but the conversion rate was $25 \%$ within $59 \mathrm{hr}$ fermentation period utilising $39.9 \mathrm{~g} \mathrm{litre}^{-1}$ of crude
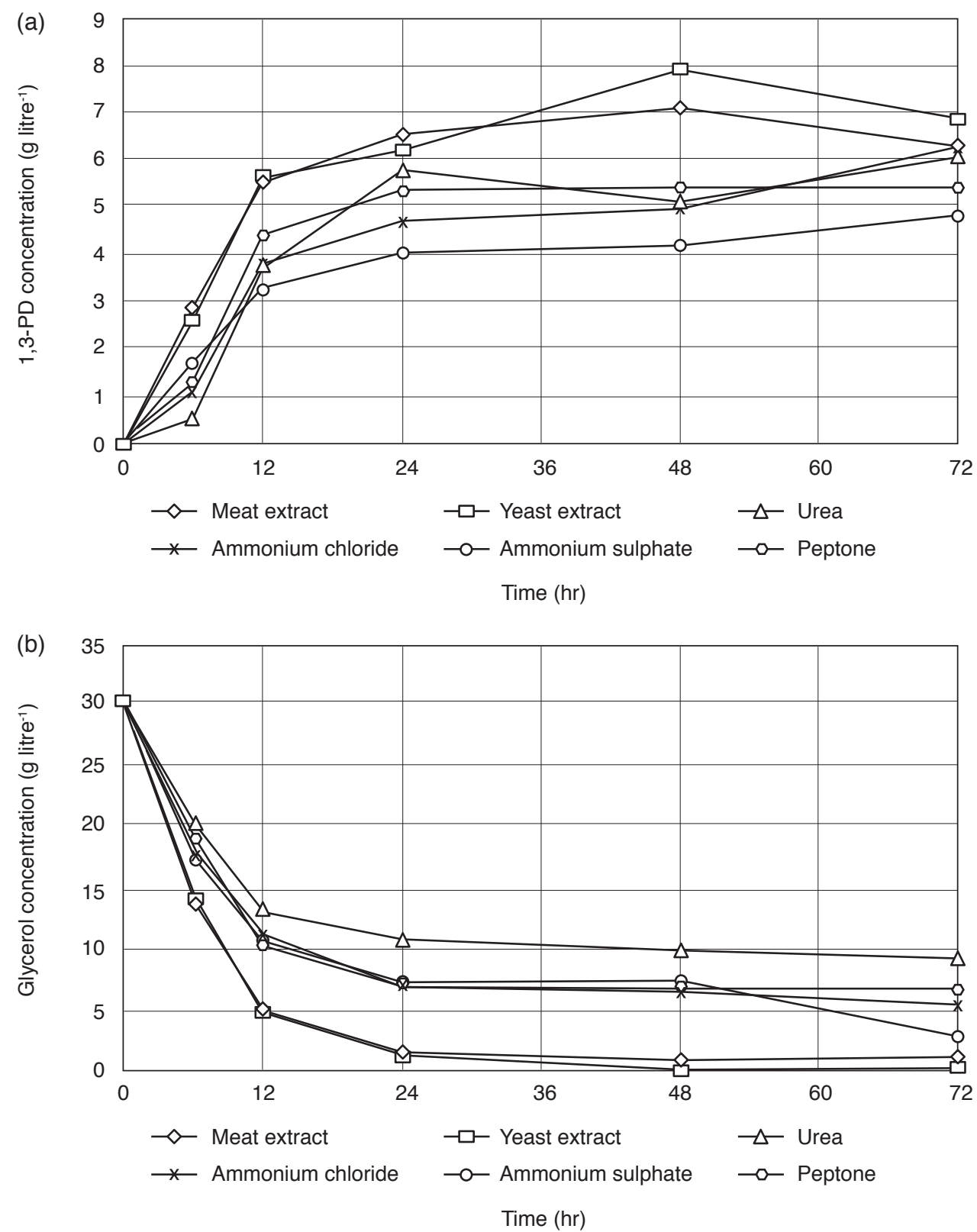

Figure 5. Screening of different nitrogen sources for production of 1, 3-propanediol (1,3-PD) by K. pneumoniae. (a) 1,3-PD production and (b) glycerol concentration. 


\begin{tabular}{|c|c|c|c|c|c|c|}
\hline \multirow{3}{*}{ Variables } & \multirow{3}{*}{$\begin{array}{l}\text { Unoptimised } \\
\text { condition }\end{array}$} & \multirow{2}{*}{\multicolumn{2}{|c|}{$\begin{array}{l}\text { Optimised } \\
\text { condition }\end{array}$}} & \multicolumn{3}{|c|}{ 1,3-PD production (g litre ${ }^{-1}$ ) } \\
\hline & & & & \multirow{2}{*}{$\begin{array}{c}\text { Before } \\
\text { optimisation }\end{array}$} & \multicolumn{2}{|c|}{ After optimisation } \\
\hline & & OFAT $^{*}$ & $\mathrm{RSM}^{* *}$ & & OFAT $^{*}$ & $\mathrm{RSM}^{* *}$ \\
\hline $\mathrm{pH}$ & 7 & 7.5 & 7.6 & - & - & - \\
\hline Temperature $\left({ }^{\circ} \mathrm{C}\right)$ & 30 & 34 & 33 & 4.89 & 8.70 & 9.85 \\
\hline Incubation time $(\mathrm{hr})$ & 48 & 48 & 59.1 & - & - & - \\
\hline Glycerol concentration (g litre ${ }^{-1}$ ) & 20 & 30 & 39.9 & - & - & - \\
\hline
\end{tabular}

glycerol. Both the OFAT and RSM optimisation employed optimal $\mathrm{pH}$ and temperature for K. pneumoniae growth in 1,3-PD production. However, the other two variables, i.e. incubation time and glycerol concentration optimised were much higher via RSM than OFAT; with only 13\% difference in yields. Thus, the OFAT approach was more practical with higher productivity at shorter fermentation time. However, the respective yields obtained were still unsatisfactory and far from being commercially attractive, thus future fed-batch optimisation study is required.

\section{CONCLUSION}

The optimum conditions achieved $(\mathrm{pH}, 7.5$; glycerol, $30 \mathrm{~g} \mathrm{litre}^{-1}$; inoculum size, $20 \%$ and temperature, $34^{\circ} \mathrm{C}$ ) had proved the importance of culture conditions via OFAT fermentation in improving 1,3-PD production. The 1,3-PD biosynthesis by $K$. pneumoniae contributed to an enhanced 1.78-fold yield and 2.59-fold productivity, respectively compared to that of the unoptimised cultivation. Furthermore, 1,3-PD production using conventional OFAT method was 13\% higher than that of RSM. The yield, however, was still not attractive and further improvement via fed-batch fermentation might be possible. Besides, the effect of varying nitrogen sources on 1,3-PD yield was less significant. The bioconversion of crude glycerol into biochemical can be an alternative solution for its undesirable disposal.

\section{ACKNOWLEDGEMENT}

The authors would like to thank the Director-General of MPOB for permission to publish this article.

\section{REFERENCES}

ANDRADE, J C and VASCONCELOS, I (2003). Continuous cultures of Clostridium acetobutylicum: culture stability and low-grade glycerol utilisation. Biotechnology Letters, 25: 121-125.

DIETZ, D and ZENG, AP (2014). Efficient production of 1,3-propanediol from fermentation of crude glycerol with mixed cultures in a simple medium. Bioprocess and Biosystems Engineering, 37: 225-233.

DROZDZYNSKA, A; PAWLICKA, J; KUBIAK, P; KOSMIDER, A; PRANKE, D; OLEJNIKSCHMIDT, $A$ and CZACZYK, K (2014). Conversion of glycerol to 1,3-propanediol by Citrobacter freundii and Hafnia alvei - newly isolated strains from the Enterobacteriaceae. New Biotechnology, 31: 402-410.

GUO, Y; DAI, L; XIN, B; TAO, F; TANG, H; SHEN, $Y$ and XU, P (2017). 1,3-Propanediol production by a newly isolated strain, Clostridium perfringens GYL. Bioresource Technology, 233: 406-412.

JALASUTRAM, V and JETTY, A (2011). Optimization of 1,3-propanediol production by Klebsiella pneumoniae 141B using Taguchi methodology: Improvement in production by co-fermentation studies. Research in Biotechnology, 2: 90-104.

JALASUTRAM, V; JETTY, A and ANUPOJU, G R (2011). Fermentative conversion of raw glycerol into 1,3-propanediol by isolated Klebsiella pneumoniae 141B strain: Optimization of culture variables. African J. Biotechnology, 10(80): 18493-18502.

JOHNSON, E E and REHMANN, L (2016). The role of 1,3-propanediol production in fermentation of glycerol by Clostridium pasteurianum. Bioresource Technology, 209: 1-7.

JONG, E D; HIGSON, A; WALSH, P and WELLISCH, M (2011). Bio-based Chemicals-value Added Products from Biorefineries. A report prepared for IEA Bioenergy-Task 42.

KANG, T S; KORBER, D R and TANAKA, T (2013). Glycerol and environmental factors: Effects on 
1,3-propanediol production and NAD+ regeneration in Lactobacillus panis PM1. J. Applied Microbiology, 115(4): 1003-1011.

LEE, C S; AROUA, M K; DAUD, W MA W; COGNET, P; PERES LUCCHESE, Y; FABRE, P L; REYNES, O and LATAPIE, L (2015). A review: Conversion of bioglycerol into 1,3 propanediol via biological and chemical method. Renewable and Sustainable Energy Reviews, 42: 963-972.

LOH, S K and STASHA, E R A (2016). Conversion of crude glycerol to 1,3-propanediol by newly isolated Kluyvera cryocrescens. J. Oil Palm Res. Vol. 28(2): 222227.

MARIA, A R; ANNAMARIA, R; ISABELLA, P; LUIGI, P; MARIA, D A and GENNARO AGRIMI (2015). Improved 1,3-propanediol synthesis from glycerol by the robust Lactobacillus reuteri strain DSM 20016. J. Microbiology and Biotechnology, 25(6): 893-902.

MOSCOVIZ, R; TRABLY, E and BERNET, N (2016). Consistent 1,3-propanediol production from glycerol in mixed culture fermentation over a wide range of pH. Biotechnology for Biofuels, 9: 32.

PAGLIARO, M; CIRIMINNA, R; KIMURA, H; ROSSI, $M$ and DELLA PINA, C (2007). From glycerol to value-added products. Angewandte Chemie International Editions, 46: 4434-4440.

PAPANIKOLAOU, S; FICK, $\mathrm{M}$ and AGGLEIS, G (2004). The effect of raw glycerol concentration on the production of 1,3-propanediol by Clostridium butyricum. J. Chemical Technology and Biotechnology, 79: 1189-1196.

RAGAUSKAS, A J; WILLIAMS, C K; DAVISON, B H; BRITOVSEK, G; CAIRNEY, J; ECKERT, C A; FREDERICK, J R; HALLETT, J P; LEAK, D J; LIOTTA, C L; MIELENZ, J R; MURPHY, R; TEMPLER, R and TSCHAPLINSKI, T (2006). The path forward for biofuels and biomaterials. Science, 311: 484-489.
RODRIGUEZ, A; WOJTUSIK, M; MORALES, V R and FELIX, G O (2015). 1,3-propanediol production from glycerol with a novel biocatalyst Shimwellia blattae ATCC 33430: Operational conditions and kinetics in batch cultivations. Bioresource Technology, 200: 830-837.

STASHA, E R A and LOH, S K (2017). Fermentation of biodiesel-derived waste for 1,3-propanediol production with response surface methodology. $J$. Oil Palm Res.Vol. 29(1): 74-80.

SATTAYASAMITSATHIT, S; METHACANON, P and PRASERTSAN, P (2011). Enhance 1,3-propanediol production from crude glycerol in batch and fedbatch fermentation with two-phase $\mathrm{pH}$-controlled strategy. Electric J. Biotechnology, 14: 6.

WOJTUSIK, M; RODRIGUEZ, A; RIPOL,V; SANTOS, V E; GARCIA, J L and GARCHIA, O L (2015). 1,3-Propanediol production by Klebsiella oxytoca NRRL-B199 from glycerol. Medium composition and operational conditions. Biotechnology Reports, 6 : 100-107.

XU, Y Y; DU, W; LIU, D H and ZENG, J (2003). A novel enzymatic route for biodiesel production from renewable oils in a solvent-free medium. Biotechnology Letters, 25: 1239-1241.

ZENG, A P and BIEBL, H (2002). Bulk chemicals from biotechnology: the case of 1,3-propanediol production and the new trends. Advance Biochemistry Engineering and Biotechnology, 74: 239-259.

ZHANG, G L; MA, B B; XU, X L and LI, C (2007). Fast conversion of glycerol to 1,3-propanediol by a new strain of Klebsiella pneumoniae. Biochemical Engineering J., 37: 256-260.

ZHAO, Z F; XU, J G and HU, Q P (2017). Optimization of fermentation conditions of glycerol to 1,3-propanediol by an alkali-resistant Klebsiella pneumonia ZH-1 using response surface methodology (RSM). Microbiology Research J. International, 18(5): 1-8. 